\title{
Scrotal Cyst
}

National Cancer Institute

\section{Source}

National Cancer Institute. Scrotal Cyst. NCI Thesaurus. Code C7746.

A cystic lesion located in the scrotum. 